\title{
Dynamics of some indicators of blood serum in case of digestive disordersin calves in the early postnatal period
}

\author{
M.S. Mannova ${ }^{1,}{ }^{*}$, L.V. Kletikova ${ }^{1}, N . N$. Yakimenko ${ }^{1}$, and K.A. Voronova ${ }^{1}$ \\ ${ }^{1}$ FSBEI HE Ivanovo Atate Agricultural Academy named after D.K. Belyaev", 153012 Ivanovo, \\ Russia
}

\begin{abstract}
Digestive disorders in calves are an urgent problem in animal husbandry. The purpose of this study was to evaluate the properties of enterosorbent and its effect on blood parameters in calves with digestive disorders. The study revealed the dynamics of total protein, albumin, globulins, protein coefficient, glucose, transaminases, creatine kinase in the blood serum of calves with digestive disorders in the early postnatal period against the background of the use of methylsilicic acid hydrogel as an intestinal sorbent. The use of enterosorbent at a dose of $0.5 \mathrm{~g} / \mathrm{kg}$ for 7 days had a positive effect on protein metabolism: the concentration of albumin increased by $10.40 \%$, the content of globulins decreased by $11.20 \%$. The activity of AST serum against the background of the use of enterosorbent was lower by $14.40 \%$ than in the control group, which indicates the detoxification properties of the drug used.
\end{abstract}

\section{Introduction}

Digestive disorders among young cattle remain one of the most urgent problems in the world practice of animal husbandry $[7,8,10]$.

Imperfection of the calves body in the early postnatal period, associated with the peculiarities of digestion, lack of proteins, especially globulins, responsible for the immune response, aggravated by untimely drinking of colostrum or its inferiority, neglect of zoohygienic norms of feeding and maintenance. Non-compliance with feeding and husbandry conditions leads to acute digestive disorders, which is manifested by diarrhea, dehydration, metabolic disorders, and, as a result, failure to receive full-fledged, healthy young animals for the herd reproduction [3]. All subclinical and clinical manifestations of pathology, as well as the influence of therapy aimed at correcting these disorders, are reflected in blood parameters changes $[1,4,11]$. Enzymes, being specific proteins, perform the role of biological catalysts in the body, affect the intensity of biochemical reactions, while normally they do not change quantitatively. An increase in enzymatic activity in the blood usually indicates the release of enzymes due to significant organic changes in the functional state of organs, due to acute or chronic diseases [3, 14]. Also, in calves of the first days of life, a decrease in enzymatic processes, in particular transaminases, leads to

\footnotetext{
* Corresponding author: mannova09@yandex.ru
} 
protein deficiency due to a decrease in the intensity of the processes of interamination and deamination [5].

Study objective: to evaluate the effect of enterosorbent in case of digestive disorders in calves in early postembryonic development on blood serum parameters.

\section{Materials and methods of research}

The object of the study was calves of the Holstein-Friesian breed of animal husbandry of the Yaroslavl region aged up to 10 days with digestive disorders. A control group $(n=10$ heads) and an experimental group ( $\mathrm{n}=12$ heads) were formed to conduct the experiment. Blood was taken from calves of control and experimental groups before and after treatment to assess the content of total protein, albumin, globulins, glucose, aspartate aminotransferase (AST), alanine aminotransferase (ALT), and creatine kinase (CK). The study was performed on a biochemical analyzer "SMT-120" (Seamaty, Spain-China).

Treatment of calves of the control group (K) was carried out according to the standard protocol adopted on the farm using the electrolyte drink "Eldiar" in a dose of $100 \mathrm{~g} / 50 \mathrm{~kg}$ by drinking 30 minutes before morning feeding; calves of the experimental group (O) were administered an enterosorbent based on methylsilicic acid hydrogel in a dose of $0.5 \mathrm{~g} / \mathrm{kg} 2$ hours after morning feeding. The course of treatment is 7 days. The clinical status of calves in both groups was evaluated before and after treatment.

\section{Results and discussion}

In a clinical study before therapy, a characteristic symptom complex was noted in sick calves: diarrhea (white-yellow feces, liquid, unformed with a sharp smell); slight depression (calves lie more); decreased appetite; during auscultation - loud, frequent, constant peristaltic noises; during bimanual palpation - tension of the abdominal wall muscles, back arching, vocalization; body temperature - within the physiological norm.

It is known that the total protein is the total concentration of albumin and globulins, while albumins provide transport of intermediate products of metabolic processes in the body and are a reserve of necessary amino acids, and globulins provide immune protection $[9,13]$. As a result of studies in calves of the control and experimental groups, the concentration of total protein and albumins in the blood serum corresponded to the reference values (see table 1). The ratio of albumin and globulins is important for the correct interpretation of the protein composition of blood serum. In sick calves before treatment, serum levels of globulins were found to be increased in the control and experimental groups of $36.3 \pm 5.03 \mathrm{~g} / 1$ and $45.8 \pm 3.9 \mathrm{~g} / \mathrm{l}$, respectively. The protein coefficient was 0.83 in the control group and 0.59 in the experimental group. Normal albumin concentrations and high globulin concentrations have been shown to indicate hypoalbuminemia masked by dehydration $[12,13]$. Based on the fact that globulins are a group of proteins that are regulators of the immune system and simultaneously non-specific protease inhibitors $[5,12,13]$, an increase in their concentration is an indicator of stimulation of the body's defenses against the background of organic and functional disorders of the gastrointestinal tract of calves, accompanied by diarrhea. Against the background of diarrhea in calves, the glucose level reached $5.83 \pm 0.93 \mathrm{mmol} / \mathrm{l}$ in the control group, and $4.85 \pm 0.84 \mathrm{mmol} / \mathrm{l}$ in the experimental group.

Aminotransferases (ALT and AST) have a direct effect on protein and carbohydrate metabolism $[2,6]$. In calves of the control and experimental groups, the ALT concentration initially corresponded to the reference values (see table 1), and the AST was reduced to $29.5 \pm 2.5 \mathrm{u} / 1$ and $46.5 \pm 20.25 \mathrm{u} / 1$, respectively. Compared with the control group, the 
activity of AST in experimental calves was $14.40 \%$ lower $(\mathrm{P} \leq 0.05)$. The concentration of $\mathrm{CK}$ in the control group was $99.5 \pm 32.75 \mathrm{u} / 1$, and in the experimental group - $106.5 \pm 2 \mathrm{u} / \mathrm{l}$. The combination of results for changes in AST and CK is a diagnostic marker of skeletal muscle damage or liver damage. In turn, creatine kinase catalyzes the reversible conversion of creatine phosphate to creatine in the presence of adenosine diphosphate (ADP), which is converted to adenosine triphosphate (ATP). The latter is a source of energy for muscle contractions [14].

Table 1. Biochemical parameters of blood serum of calves of the control and experimental groups, $\mathrm{M} \pm \mathrm{m}$

\begin{tabular}{|l|c|c|c|c|}
\hline \multirow{2}{*}{ Indicators } & \multicolumn{2}{|c|}{ Before treatment } & \multicolumn{2}{c|}{ After treatment } \\
\cline { 2 - 5 } & $\mathrm{K}(\mathrm{n}=10)$ & $\mathrm{O}(\mathrm{n}=12)$ & $\mathrm{K}(\mathrm{n}=10)$ & $\mathrm{O}(\mathrm{n}=12)$ \\
\hline Total protein, g/l & $65.60 \pm 3.95$ & $72.30 \pm 4.06$ & $64.95 \pm 4.00$ & $69.92 \pm 4.11$ \\
\hline Albumin, g/l & $29.30 \pm 1.10$ & $26.55 \pm 2.65$ & $31.37 \pm 0.88$ & $29.30 \pm 1.53$ \\
\hline Globulins, g/l & $36.30 \pm 5.03$ & $45.80 \pm 3.90$ & $33.57 \pm 4.88$ & $40.65 \pm 3.10$ \\
\hline Protein coefficient & $0.83 \pm 0.14$ & $0.59 \pm 0.07$ & $0.96 \pm 0.16$ & $0.83 \pm 3.71$ \\
\hline Glucose, mmol/1 & $5.83 \pm 0.93$ & $4.85 \pm 0.84$ & $6.64 \pm 0.52$ & $6.15 \pm 0.75$ \\
\hline AST, u/l & $29.50 \pm 2.50$ & $46.50 \pm 20.25$ & $36.50 \pm 3.00$ & $31.25 \pm 4.25$ \\
\hline ALT, u/l & $6.13 \pm 2.44$ & $5.50 \pm 1.00$ & $4.28 \pm 0.28$ & $4.75 \pm 0.15$ \\
\hline CK, u/l & $99 t .50 \pm 32.75$ & $106.50 \pm 32.00$ & $242.00 \pm 75.00$ & $113.50 \pm 8.50$ \\
\hline
\end{tabular}

After a seven-day course of treatment, appetite was restored in calves from the control group, there was no pain during palpation, the act of defecation was not disturbed in $80 \%$ of calves, and the physical and chemical properties of feces corresponded to physiological parameters. In calves of the experimental group, clinical signs reflecting pathological processes were absent in $100 \%$ of cases.

A repeated study of blood serum showed a tendency towards a decrease in total protein in both groups, as well as a decrease in the concentration of globulin in the control group by $7.50 \%$,

in the experimental group by $11.20 \%$, and a corresponding increase in albumin and protein coefficient by $7.10 \%$, and $10.40 \%$; by $15.70 \%$ and $40.70 \%(\mathrm{P} \leq 0.05)$.

Glucose levels in the control and experimental groups increased by $13.90 \%$ and $26.80 \%$, respectively. The increase in glucose in the repeated study of serum in both groups of animals can be explained by the fact that one of the main components of the electrolyte drink "Eldiar" is glucose, which accumulates in the blood and depositing organs.

The AST concentration in the control group increased by $23.70 \%$, in the experimental group, on the contrary, decreased by $32.80 \%$, ALT significantly decreased in both groups, respectively, by $30.20 \%$ and $13.60 \%$. CK activity increased in the control group to $242.00 \pm 7.50 \mathrm{u} / 1$, and in the experimental group - to $113.50 \pm 8.50 \mathrm{u} / 1$, but did not exceed the reference range. The difference between the control and experimental groups is due to increased peristalsis in this pathological condition, which is confirmed by clinical signs in the control group and the positive effect of enterosorbent in the treatment of calves with digestive disorders on the seventh day of treatment. 


\section{Conclusion}

Before the use of drugs in calves of both groups, the indicators of total protein, albumins, ALT, CK corresponded to the reference values, the level of globulins, glucose was increased, and AST was reduced. Identification of the relationship between the protein composition and enzymatic activity of blood serum before and after treatment indicates the severity of the pathological process and the positive effect of the drug in the scheme of standard treatment accepted on the farm. The presence of a sorbent levels the toxic effect of metabolites on the liver, as the main organ providing detoxifying function. A more pronounced decrease in the level of globulins, an increase in the protein coefficient, a moderate increase in the level of CK in the blood serum of calves in the experimental group on the seventh day indicate a positive effect of enterosorbent at a dose of $0.5 \mathrm{~g} / \mathrm{kg}$, along with a positive dynamics of clinical status.

\section{Acknowledgment}

The study was supported by the Ministry of Agriculture of the Russian Federation in 2020.

\section{References}

1. I.I. Kalyuzhny, Clinical gastroenterology of animals (SPb.: Lan, 2015)

2. G.N. Levina, K.E. Tikhonov, A.I. Nazarenko, M.V. Zelepukina, R.A. Rykov, News of the Timiryazevsk Agricultural Academy, 5, 106-115 (2019)

3. Yu.G. Lyakh, Animal husbandry and veterinary medicine", 3, 35-41 (2015)

4. M.S. Mannova, Actual issues of Agricultural biology. Belgorod, 3(17), 121-126 (2020)

5. S.Yu. Olkhovsky, T.V. Olkhovskaya, Veterinary Petersburg, 1, 21-23 (2012)

6. S.L. Safronov, A.E. Belopolsky, N.V. Fomina, Izvestiya of the Saint-Petersburg State Agrarian University, 2, 82-87 (2020)

7. I.O. Skorykh, Metabolism in newborn calves in normal and dyspepsia: Diss cand. of vet. sc. (06.02.01) (Barnaul, 2015)

8. N.N. Yakimenko, M.S. Mannova, L.V. Kletikova, N.P. Shishkina, Bulletin of the Kursk State Agricultural Academy, 5, 105-110 (2020)

9. N.N. Yakimenko, M.S. Mannova, L.V. Kletikova, D.I. Sinelshchikova, N.P. Shishkina, BIO, 4, 12-14 (2020)

10. Q. Diao, Zhang R., Fu T., Animals (Basel), 9(8) 490 (2019)

11. T. Ling, M. Hernandez-Jover, L.M. Sordillo, A. Abuelo, J. Dairy Sci., 101(7), 65686580 (2018)

12. C. Tothova, P. Mudron, O. Nagy, Acta Veterinaria-Beograd, 67(2), 178-190 (2017)

13. C. Tothova, O. Nagy, Mihajlovicova X., Oskar Nagy, Ruminants - The Husbandry, Economic and Health Aspects, 105-14 (2017)

14. J. Weber, M. Zenker, G. Köller, M.Fürll, M. Freick, Journal of Veterinary Research, 63(3), 383-390 (2019) 